\title{
Incorporating Authentic Materials and Digital Taxonomy in Teaching English: Pragmatic Innovation Through Integrative CALL
}

\author{
Ahmed Al Shlowiy ${ }^{1} \&$ Marvin Wacnag Lidawan ${ }^{1}$ \\ ${ }^{1}$ English Language Institute, Education Sector, Royal Commission for Jubail, Saudi Arabia \\ Correspondence: Ahmed Al Shlowiy, English Language Institute, Education Sector, Royal Commission for \\ Jubail, Saudi Arabia. E-mail: shlowiy_a@jic.edu.sa
}

Received: September 11, 2019 Accepted: October 8, 2019 Online Published: October 28, 2019

doi:10.5539/ijel.v9n6p292 URL: https://doi.org/10.5539/ijel.v9n6p292

\begin{abstract}
This article centers on the development of multimedia and technology that proliferates around 21st century English language learners creating a media_rich environment, but accessibility of these may not be similar on how other learners may benefit. This imparts how learners benefit indiscriminately through integrative Computer Assisted Language Learning (CALL) with pragmatic tasks from authentic materials incorporating digital taxonomy. As adapted methods, a rigid review of related studies and practical examples to underpin three conceptualized techniques. These were subjected for exemplification in the discussion: (a) producing varied independent outputs through different materials, (b) creating a single independent output through intertwined task from a single material, and (c) producing varied independent outputs from varied tasks through a single material. It is recommended that researches alluding to this paper must be conducted quantitatively to find out the correlation or significance of students' critical thinking achievement with the engagement of digital taxonomy such as what Cotton (1991) emphasized that Computer Assisted Instruction aids the development of students' critical thinking in which learners' Higher Order Thinking skills (HOTs) activities are generated from varied computer manipulation. She further supported her study and claims through experimental researches conducted by Bass and Perkins (1984); Riding and Powell (1987); Pogrow (1988) and Baum (1990) that tend to be dominant manifestations prior to the formal discovery of digital taxonomy, its importance has been pioneered by several scholars.
\end{abstract}

Keywords: digital taxonomy and authentic materials, order thinking skills, innovation, CALL, digital taxonomy for ESL

\section{Introduction}

"Those who know, do. Those that understand, teach."

-Aristotle

\subsection{Authentic Materials in Mass Media and Technology-Rich Environment}

The fruition of technology nowadays exposes authentic materials as one of the primary springboards for language learning propelled by media forms where immediate access to these for instructions is eased by varied forms of technology. It is perceived that the manipulation of authentic materials as inputs in the classroom instructions may lead to language learning alongside with familiarization of media and technology. Since media forms are dependent upon technology, technical instructions are incorporated. Likewise, when these materials are operated as toolkits for target language' achievement, macro skills together with viewing skill is further strengthened.

To facilitate favorable results of these materials, it is the teacher's creative goal to design communicative tasks out of authentic toolkits linking to Nunan's (1999) definition. To him, authentic materials are real-world spoken or written language information. When teachers conceptualized techniques in imparting language in a natural way, communicative competence is possibly achieved. This connects to Canale and Swain's (1980) study which highlights, languages learned in real contexts for students' grammatical, sociolinguistic, discourse and strategic competence. Communicative competence can be activated and enhanced depending on the frequency of authentic materials' use, teachers' level of practices and digital tools. At this effect, students may learn the target language, media forms and digital skills due to computer-based knowledge. In other words, communicative approach to language teaching may be intensified by modern authentic materials from mass media forms constantly linked 
with technological tools such as computers for teachers' classroom facilitation.

McKenzie (2012) adheres to this idea by affirming that today's classroom should support learning styles while incorporating technology in a real-life manner. This links to the significance of Hobbs's (2011) study which emphasizes that teachers who are already using authentic materials, such as news media, popular culture, and digital media to support academic achievement in language arts, science, history, and the arts are discovering the power of connecting students' digital learning skills. Hobbs asserts that students' enjoyment through digital engagement in media literacy-related programs such as using computers and the Internet stretches their critical thinking and operative skills.

In language instruction, the best setting for acquiring English occurs in a natural setting (Lave \& Wenger, 1991). Learning in natural settings occurs as a function of authentic activities or real-life (Lantolf, 2000). In the 21st century, creating authentic activities in a language-learning setting is possible due to the Internet or other technological tools (Zong, 2008). These learning activities connect students' theoretical knowledge to real-life applications. The tasks further bridge the contextual gap between technology, learning environments, and pedagogy. The activities may also allow the exploration of new knowledge in context (Banas \& York, 2014) and enable teachers to overcome the students' individual differences (Alshumaimeri \& Alzyadi, 2015).

Today, students are described as "native digital" students (Prensky, 2001) because they are surrounded with digital devices and live in the digital age. They are part of the "net generation" (McLoughlin \& Lee, 2007) who are exposed to communication technologies, which have become part of their daily lives. Such learners "process information and learn differently than their teachers, they will be less accepting of traditional definitions of 'classroom' and 'class participation' and the roles assigned to teachers, and they will use technology as a tool for creative expression" (Thorne \& Payne, 2005, p. 380). The digital-generation students tended to be more independent in their studies (McLoughlin \& Lee, 2007). When learners think about how they can learn (Lantolf, 2000), they explore opportunities to learn and revise their actions based on past mistakes (Kao, 2008).

Moreover, students understand their own needs, interests, and challenges as non-native English learners and as the "net generation" (McLoughlin \& Lee, 2007). They sought immediate feedback, accessibility to information, an interactive environment, multi-media application availability, teamwork with others, connectivity, hands-on experiences, inquiry-based approaches, and self-directed learning opportunities (Barnes, Marateo, \& Ferris, 2007). Therefore, such generation of students requires web-based teaching approaches (Mahib urRahman \& Alhaisoni, 2013). Teachers should offer native digital students satisfactory support, guidelines, and environment that develop their study skills and enhance ways to be independent learners.

When we combine mass media authentic materials, computers, Internet Applications and digital taxonomy in language learning tasks, these components lead to the employment of integrative CALL.

\section{Literature Review}

\subsection{The Significant Role of Integrative Computer Assisted Language Learning}

Integration of modern authentic materials for language instructions alongside digital taxonomy anchored to learning outcomes need appropriate educational technologies. Unfortunately, not all educational organizations can afford the ideal forms of technologies to be attuned with the trending times for learners' immersion. To exemplify this, Kuang's (2000) study on the obstacles of using educational technologies pinpointed the high costs of technologies. Technologies' expensive prices elucidate financial barriers among learners. However, the said problem could be soon solved when Hooper (1995) noted years earlier that the cost of computers will be soon inexpensive. Today, Hooper's statement shows observable significance. As an alternative in coping with educational institutions' deficiency of procuring advanced technological tools for instructions, innovation among teachers is practically probable through Computer Assisted Language Learning (CALL).

Looking back at the history of CALL, it emerged in the United Kingdom which primarily focused on learning than giving directions through computer-assistance. The earliest record which CALL could be found was on a workshop paper authored by Davies and Steel in 1981. The following year, CALL became prevalent in language teaching around the world (Davis \& Steel, 1981, as cited in Thomas, Hayo, \& Warschauer, 2013).

Many scholars recognize the potential of CALL. Warschauer and Healey (1998) reiterate that Integrative CALL attunes to modern learners applied through multimedia computers and Website applications. In here, all sources are connected by hypermedia for learners to be able to access the resources.

In connection to CALL, hypermedia is relative to the use of computers and Internet applications. The involvement of hypermedia, computers and Internet applications indicate a clear understanding of how CALL can be employed. To clarify this idea, Warschauer (1996) declares further that hypermedia can create more real learning settings, 
easy integration of macro skills with viewing skills can be enhanced. It also facilitates learning convenience due to the learner's control of time frame. Moreover, it allows students' standard focus on content forms and learning approaches.

Additionally, many researches show the significant involvement of CALL to process language tasks in formal language teaching if lessons are well-assisted and planned. To support this claim, Jones and Fortescue (1988) reveal that CALL introduces computers as adjustable classroom for those involved in learning and teaching. It also provides varied settings and procedures dependent upon learning aims which need to be appropriately organized. Rogers (1988) further reveals that behaviorism scholars discovered understandable effects of teaching through computer-assisted instruction. Furthermore, he points out that CALL is appropriate to process auditory and visual mass media for students' language awareness. He explicates that the employment of multimedia technologies in language teaching specifically computers, can yield favorable results in instructions.

Today, CALL has developed into a higher form which is called, integrative CALL. Moreover, observable principles connect to the concept of this paper as Warschauer and Healey (1998) reveal contemporary standpoints on integrative CALL. Both reiterated on the relevance of technological tools to regularly play crucial roles for new second language learning and socio-cognitive interpretation process. They also asserted on integrative CALL that paved the emergence of social and learner-focused approaches such as task-based and project-based where language is used in a real social situation.

Also, several researchers claim that CALL generally indicates favorable significance to learners. For example, Jeong (2007) gathered data indicates that the Internet is a useful instrument in obtaining and processing additional ESL learning materials. His study reveals that learners' involvement and attitudes to Internet-suggested activities were favorably perceived. He recommends that further researches involving Internet contents should be conducted to enhance understanding on how the websites are used in learners' language acquisition. In his investigation, Internet was one of the sources for language achievement which indicate computers' significance. Jeong's study points out to an integrative CALL which this paper attempts to integrate.

In computer-related teaching, Abu-Seileek's (2004) findings showed that respondents who studied through computer-instructed tasks have higher achievement than those who were traditionally instructed. Results manifested. Also, McEnery, Barker, and Wilson's (1995) study on the use of computers for second language learning manifested that computer-based grammar instruction seem to demonstrate more effective outcomes than the traditional instruction. Essentially, Salomon (1997) suggests that the central components of classroom environments when integrating CALL may include task, sense of control, teacher-student collaboration, student-student collaboration, setting, and teacher behavior. Salomon further asserts that these components infuse instructional knowledge.

Likewise, Chapelle (1998) proposes seven theories that are relevant to develop CALL setting. Chapelle includes: (1) language focus, (2) language inputs' semantic and syntactic aspect, meaning and structure, (3) learners' production of an output, (4) learners' knowledge of their errors, (5) learners' corrections of their errors, (6) learners' interactive involvement through languages, and (7) learners engagement in the second language through prior knowledge as reinforcement. To emphasize, Chapelle (1998) and Salomon's (1997) suggestions closely adhere to the concept of which this paper aims to share to prospective readers.

Amiri, Hashemy and Hayati (2012) and Motteram (2013) propose that technology and the Internet show potentials on how students learn. To them, the worldwide web is a modern and ideal way to be able to learn if aided by multimedia and technology. To them, collaborative learning or independent learning could be applied as classroom setting. Furthermore, both agree that using computers and the Internet achieve situational learning, such as computer-mediated communication and accessing resources.

In conformity to other researches, Hamlaoui and Benabdallah (2015) expose their study on effectiveness of the Digital Dedicated Language Laboratory (DDLL) in teaching English through a discussion-based approach. They claimed that well-designed protocol and an intelligent exploitation of the DDLL potentialities will develop English language learning through discussions. Their research could encourage others to undertake other action research projects related to the integration of contemporary technological tools.

In addition, Al Khayyat (2015) elaborated that presentation of materials in an integrative way via CALL has developed students' proficiency in the four skills. The researcher believes that the CALL program could be anchored to Krashen's Monitor Model Hypothesis where "input hypothesis" should be comprehensible, interesting, and relevant.

Additionally, an innovative teaching methodology conducted by Latif (2012) reveals that through the Internet, 
instructors and learners can swap data and information using virtual resources like virtual libraries for learners to explore more opportunity and keep their knowledge updated while having exposure to the target language. To Latif, manipulation of technology delivers the mood of distributed cognition theory. When socio-cognition occurs, information is being shared.

Similarly, Abdallah and Mansour (2015) divulge that employing a virtual task-based situated language learning or (TBSLL) environment reveal the effectiveness of the TBSLL design within the SL environment in developing participants' pragmatic writing and technological self-efficacy. Furthermore, a strong connection was found between pragmatic writing test and technological self-efficacy. It means that when researchers analyzed the new learning environment design and interactive features, it showed the TBSLL's effectiveness. This could be closely connected to the idea of this study that aims to students' linguistic and technological awareness. When both are infused, order thinking skills increase cognitive knowledge.

\subsection{The Nature of Authentic Materials}

Authentic materials are relevant inputs for a successful employment of integrative CALL. It is perceived to support language instructions through real-life learning activities. The Internet has numerous authentic learning materials, such as videos, virtual radio, news channels, application forms, magazine articles, newspaper reports, television advertisements, and chat communities (Zong, 2008). To Zong, these materials tend to be useful in language teaching. This is further supported by Nuttal (1996) through affirming that authentic text may be motivating since they serve as evidence that the language is used in real-life settings, as Breen (1985) highlights that the kinds of tasks from authentic materials immerse learners in genuine communication interaction.

Moreover, authentic materials are further emphasized by Brosnan, Brown, and Hood, (1984) by advocating that when we have these instructive springboards, we simplify the language for instructive purposes. To them, even a small amount of material can serve relevant pedagogic activities. Furthermore, Brosnan et al. (1984) state that authentic materials, such as pictures, symbols, or colors enhance students' comprehension, when they are operatively used. To add, Berardo (2006) discloses that anything can be used as authentic materials in the classroom. He further declares that one of the most useful resources is the Internet since diverse amount of materials are accessible from it. Also, Brinton (2001) advocates that authentic materials and media can strongly connect to language settings inside and outside the classrooms. This is further emphasized by Melvin and Stout (1987) who reiterate that authentic materials raise students' language learning motivation and engagement when they are introduced to teach culture.

\subsection{Viability and Classification of Authentic Materials}

To determine the viability of authentic material employed in language instructions, we pattern from Richards's (2001) criteria through the following conditions:

- If they provide favorable effects on the learners' interests.

- If they deliver or relay cultural knowledge.

- If they provide practice on learners to deal with real, language.

- If they connect thoroughly with the learners' needs.

- If they can sustain more innovative approach for teachers.

To understand the types of materials to be employed, Gebhard (1996) classified them according to: authentic listening, viewing, authentic visual and authentic printed materials.

In establishing a close association of the tasks to these authentic materials' three categories and viability set out by two proponents, the writers followed these principles in tasks presentations embedded under the discussion through three tables.

\subsection{Authentic Materials, Media, and Digital Technological Instruments}

Several scholars perceive close linkages among authentic materials, media, and technology in instructions. Initially, Motteram (2013) states that the benefits of technology are integrated with project work that encourages students to learn a variety of language. Motteram suggests that learners' skills are enhanced by topics attuning to their interests. In conjunction to the latest statement, Zhu (2003) reveals that theory, pedagogy, and technology are essential components in today's contemporary learning as seen instructional technology curriculum. These sources are largely in forms of authentic materials through the employment of search engines, such as Google Chrome and Firefox Mozilla. The teachers' method in searching for materials is tantamount on how students will undergo the tasks that were designed for them. 
Moreover, Jenkins (2009) emphasizes that students' need to take part in cultural interactions through social media can yield the high possibility of content delivery, collaboration, and assessment. He elaborates that utilization of these tools reinforces learning. Technological tools using authentic materials can serve as beginners' learning process for they could create social settings in which learners have many interactive opportunities for authentic practices. Additionally, Lombardi (2007) advocates the advantages of using technology for situational learning such as computer-aided communication in a classroom and retrieving ideas from the Internet. Lombardi further asserts that technology can support learning involving authentic materials through preparation and presentation of lessons, Internet connectivity, online communication as well as social networking tools.

\subsection{Authentic Materials in Varied Classifications}

Inputs of task designs for integrative CALL require varied types of authentic materials that are basically obtained from the Web. To support, Tuzi, Mori, and Young (2008) state that aired or broadcast commercials have authentic contents which are written and spoken for native speakers. Similarly, Lovell (1987) points out that films have been advocated by American higher educational organizations where most institutions followed globally and that they are used to launch a social situation for English as a second language teaching. Additionally, in films, Wood (1995) narrates that film communication offers links between classrooms and society, explores cultural context and may be integrated easily into the curriculum. To add, they act as foci for teacher-student interaction and promotes awareness of the interrelationship between modes through pictures, movements, languages, sounds, and captions. Furthermore, Zhang (2012) exposes that through films, teachers can advance the students' ability in cross-cultural communication, language proficiency levels, macro skills, and vocabulary. Also, on film's musical scoring, Williams (1999) declares that teaching music from films by associating to language and literature can be ideal springboards. To him, combining these elements arouse imaginative progression for learners to attain academic abilities. More on the benefits of authentic materials, Reisland (2009) points out that advertisements promote learners' audio and visual literacy. Additionally, Reisland highlights that media has a wide coverage, such as newspapers, films and televisions which are possible for instructions.

Real life materials, such as pictures, graphs, stamps, cartoons, book covers, paintings, charts, other graphic forms, and posters can represent the nature of authentic visual materials that focus more on figures or images for comprehension. On visual authentic material, Miller (2011) observe that poster utilization can enable students to produce a variety of vocabularies, phrases, and sentences and even form narratives through teachers' strategies. Moreover, a study exposing students on visuals reveal an effective approach for introducing concrete concepts to learners. To elaborate the significance of manipulating visuals, three design principles by Lohr (2003) can assist instructional designers in dealing with visual aids. These are the figure-ground principle, hierarchy principle and the gestalt principle. These principles support the fruition of students' abilities to understand visual materials.

Furthermore, Lavery (2015) shares that cartoons and comic strips can be used for language instructions in wide-ranging language exercises. Similarly, in relation to imagery, Ferlazzo (2012) declares that pictures or photos can effectively established brainstorming such as the Picture-Word-Inductive Model (PWIM). Moreover, according to Zucker, Staut and Tinker (2015) Common Core State Standards-English and Language Arts (CCSS-ELA), teachers could provide students proper comprehension of information including science materials that are emphasized in all sorts of reading resources, such as books, magazines, and newspapers as well as the website. Moreover, Bayri's (2010) study reveals that the visual nature of the art such as paintings may aid learners to acquire new words when using cultural and contextual points of view. His findings disclose that art-exposed students on a variety of vocabulary and command of language than students who were not exposed to them.

McGrath, (2002) discloses that texts from authentic printed materials are functional when they generate the development of reading skills. To achieve this possibility, these words should be simplified for easy understanding. The use of authentic texts has been supported earlier by Firth (1957) who argues that language should be studied in actual, attested, authentic instances of use. He further argues that placing a text as a constituent in a context contributes to the statement of meaning since situations are set up to recognize meaning. Likewise on film script involvement, Sweeting (2009) advocates that the use of scenes can aid learners in identifying themes, such as sarcasm by providing worksheets with significant lines from the movie script to be interpreted. In advertising as authentic materials, studies in linguistic standpoints have been attempted by several scholars who perceived advertisements as effective tools for language interplay. To underpin this claim, Leech's (1966) ground-breaking and comprehensive study on English advertising has analyzed different aspects referring to grammar, vocabulary, discourse, rhyme, and rhetoric. Leech has related these aspects towards functional factors, such as attention value, readability, memorability and selling power. To Leech, having these characteristics can trigger language learning when advertisements are used in language classrooms. 
Likewise, Vestergaard and Schroder (1985) have studied the language use in commercial press advertising by verifying several communicative functions of language, such as expressive, directive, informational, metalingual, interactional, contextual, and poetic. Since these features are embedded, advertisements are claimed to possess strong authentic materials that can trigger language learning. Another inquisition on authentic printed material specifically, editorials, conducted by Afzal and Harun (2013) reveals that editorials can probably aid in English language acquisition. To them, editorials can serve as patterns for writing activities. Recipes are seen to be potential authentic materials. Eisenberg (2014) admits that recipes offer actual experiences while building contextual diagrams. These serve as forms of writing exercises for real contextual passages for learners' language engagement. Equally important, Tomalin and Stempleski (1988) mention that the use of cultural objects exhibit powerful effects in language classrooms which they used as bases in conceptualizing cultural compositions for the enhancement of writing skills. Lastly, song lyrics are found to be ideal learning inputs. Coats (2016) shares that students have global access to song lyrics as texts or as audio materials in the classrooms. To her, understanding musical expressions is similar to comprehending language, culture, and humanity.

\subsection{Authentic Materials' Links to Curriculum}

This portion showcases some effects of the varied types of authentic materials, their connections to intended learning outcomes and how they are linked to curriculum as perceived by proponents.

Primarily, Zane Education (2015) advocates that video is the best catalyst of instructions among visual and auditory learners due to the presence of subtitles and the images. Zane Education advises teachers to use video as an instructional tool by observing its alliance to the specific learning objectives of institutions' mandated English language curriculum. Moreover, Griffin (2015) stresses that specific learning objectives should be determined prior to administering the language tasks. Griffin cites further that out of authentic materials, instructional sequences should be developed through well-prepared reinforcement activities. Authentic materials may exist in varied forms but their usages and their favorable effects in instructions and to the English curricula unify them in common sets of goals. Here are some indications.

Abbasian, Mahmoudi, and Shahbazi (2016) reveal that in the present day, authentic materials are useful to material designers and curriculum developers in revolutionizing traditional methods to communicative language teaching approach as indicated by students' acceptable competency levels. To them, involvement of authentic materials transforms teaching into a contemporary curriculum. Another study shows a positive outcome on the effects of authentic materials in an EFL classroom.

Losada, Insuasty, and Osorio's (2016) study reveals that authentic materials created significant impact towards the enhancement of students' vocabulary levels, cultural knowledge and the range of their focus towards learning. They endorse that there should be an organized implementation of authentic materials in foreign language situation which can be connected to the materials, school's educational context as well as teachers' sufficient knowledge. These materials are apparent through the presence of technology that controls media forms. The incorporation of media forms in current language instructions alongside authentic materials creates learners' digital knowledge. Finally, learners are immersed in concrete and meaningful communicative activities with other people (Lantolf, 2000). It is then crucial that the proliferation of media forms should be linked to curricular designs. One of the major rudiments of applying CALL is to arrive at intended outcomes to be able to measure students' performance.

\section{Discussion}

\subsection{Building Authentic Materials' Tasks Integrating Digital Taxonomy Through Integrative CALL Principles as Bases of Outputs}

Originally, Bloom's Taxonomy of Objectives that sequence learners' levels of thinking skills are comprised of knowledge, comprehension, application, analysis, synthesis, and evaluation. Then further studies by Anderson and Krathwohl (2001) revised into remember, understand, apply, analyze, evaluate, and create with corresponding subskills in noun forms. Due to the onset of technology, Bloom's Taxonomy of cognitive domain turned into Digital Taxonomy by Churches (2008) transforming the Lower Order Thinking Skills (LOTS) into Remembering, understanding while the Higher Order Thinking Skills (HOTS) were expressed into applying, analyzing, evaluating and creating with corresponding subskills in noun forms. Churches' Digital Taxonomy is the fundamental framework in introducing the outputs' progressions.

\subsection{Producing the Outputs}

This paper specifically centers on the cognitive processes attained by learners with the use of authentic materials, designed digital and linguistic tasks and the order thinking skills aided by multimedia, such as computers and Internet-based applications. The procedures of producing the intended outputs are crucially supported by the 
principles behind integrative CALL and teachers' systematic facilitation. As used in this study, its pedagogical approach is task-based and content based with the aid of computers and multimedia applications to incorporate digital taxonomy.

The tasks are presented in three varied tables which could be administered to students individually or collaboratively to arrive on intended outputs. Table 1 comprises the cognitive processes using varied authentic materials to produce independent outputs. Table 2 consists of the cognitive processes using single authentic material with intertwined tasks to produce dependent outputs for the purpose of generating an over-all input. Table 3 centers on cognitive processes through a single authentic material to generate independent outputs. All these tasks under the three tables contain authentic tasks elements namely: (1) specific authentic input, (2) language target(s), (3) specific objective(s), (4) expected output, (5) technological aid(s), (6) skills, and (7) type of authentic material. These tasks have employed any among authentic listening-viewing materials, authentic visual materials, and authentic printed materials.

Table 1. Authentic materials with varied tasks producing varied independent outputs

\begin{tabular}{ll}
\hline Digital Taxonomy & $\begin{array}{l}\text { Digital and Linguistic Skills from Authentic } \\
\text { Materials }\end{array}$ \\
\cline { 2 - 3 } 1. Remembering & $\begin{array}{l}\text { Lower Order Thinking Skills (LOTS) Lower Le } \\
\text { find topics on disasters in the website and } \\
\text { bookmarking these topics }\end{array}$ \\
in the featured video clip \\
- Disting of all images and actions that are se \\
presented
\end{tabular}

- Identifying Wh-questions from an interview flashed on screen

- $\quad$ Retrieving functional features from a products' technical specification

- $\quad$ Bullet pointing transitional words in a process exposition from a passage obtained from the web

- $\quad$ Highlighting the title, topic sentences in a paragraph using color codes in Microsoft word applications

- $\quad$ Social networking/sharing with fellow students on topics assigned by the teacher to brainstorm words from an editorial article

- $\quad$ Googling/copying/searching pictures about people animals and places

\section{Authentic Task Elements}

(1) authentic input (2) language target/s (3) specific objectives (4) expected output (5) technological aid/s (6) Skills (7) type of authentic material

\section{(1) topics on world disasters/dates (2) English}

alphabets/dates (3) search, list, recognize, bookmark (4) alphabetized list and sequenced topics according to dates (5) Websites and computers (6) reading and writing (7) authentic printed materials

(1) video clip (2) verbs and nouns for vocabulary study (3) sentence constructions \& word definitions (4.) list or enumerate. (5) cd, external drive, computers, projectors, blackboard (6) listening, viewing, reading and speaking (7) authentic listening-viewing materials

1) music video (2) Adjectives (3) describe (4) adjectives as modifiers and phrasal constructions (5) YouTube, computers, scanners, projectors (6) viewing, listening, writing and speaking (7) authentic listening-viewing materials

(1) job interview sample (2) wh-questions/interrogative pronouns (3) specific objectives: identify (4) reconstructed interview (5) projector/ computer/cd player (6) listening, viewing, speaking and writing (7) authentic listening-viewing materials

(1) Samsung Phone Unit product specification (2) verbs use in singular and plural subjects (3) retrieve (4) Functions of parts (5) Internet/computer/ (6) reading and writing (7) authentic printed material

(1) downloaded user guide on rice cooker. (2) Process expressions (3) Bullet-point/identify/mark (4) Highlighted process expressions (5) Projector and computer Microsoft word application (6) reading (7) authentic printed material

(1) downloaded article on deforestation (2) parts of a paragraph (3) label/ highlight/mark (4) labeled paragraphs' parts (5) Computer/projector (6) reading (7) authentic printed material

(1) uploaded vocabularies by the teacher from editorial article (2) word formation (3) locate and list related words and share (4) brainstormed words (5) computer, blackboard, projector for class reports and discussions (6) reading and writing with vocabulary skills (7) authentic printed material

(1) Internet features on people, animals and places (2) nouns (3) search and copy (4) Googled labeled pictures (5) Internet/scanner/external disc and projector (6) viewing (7) authentic listening-viewing materials 
2. Understanding • $\quad$ Summarizing the experience of a soldier taken from a blog

- $\quad$ Explaining airline schedules

- $\quad$ Twittering news and information to classmates

- Captioning and tagging picture to your friends to comment on Facebook

- $\quad$ Subscribing to a LinkedIn for social networking
(1) blog (2) past simple (3) summarize account (4) narrative summary of experiences (5) Internet/computer (6) reading and writing (7) authentic printed material (1) airlines flight schedules (2) time expressions (3) explain (4) tabulated schedules (5) computer/projector (6) writing and speaking (7) authentic printed materials (1) news item (2) declaratives (3) tweet (4) tweeted info (5) computer/phone (6) reading \& writing (7) authentic printed material

(1) winter picture (2) simple present (3) caption and tag (4) captioned photo (5) computer/Tablet/phone (6) writing (7) authentic listening-viewing materials (1) LinkedIn data (2) vocabulary for personal information (3) subscribe (4) completed data sheet (5) computer/ tablet/phone (6) writing (7) authentic printed material

\begin{tabular}{l} 
Higher Order Thinking Skills Higher Level Objec \\
\hline 3. Applying $\quad$ Operating computer before delivering \\
PowerPoint presentation on how to prepare the \\
usage of computer and projector \\
- Using a PowerPoint to explain an assigned \\
with pictures \\
- Uploading your poems in a Facebook or in a \\
blog
\end{tabular}

- $\quad$ Sharing info about your favorite film actor's biography in social media

- $\quad$ Editing the rhyme schemes by substituting words based from a cyber poem

\section{Analyzing}

- $\quad$ Structuring the themes of a given passage taken from the Internet using a schema in forms of content words.

- Integrating captions using of a downloaded photo on working people before displaying and printing

\section{Evaluating}

- Validating the recipe's process by noting the ingredients and the procedures involve categorizing after listening and viewing

- $\quad$ Critiquing an article obtained from a blog through considering weak and dominant points of the work in columns

- $\quad$ Posting and suggesting comments and suggestions after reading an excerpted passage uploaded in the Blackboard system

- Collaborating with a classmate in listening to an interview to obtain appropriate information to rewrite a timeline.

- $\quad$ Reviewing a film clip regarding war to be able to determine the adverse effects and provide advices among readers
(1) computer and projector user manual (2) process expressions (3) operate (4) presentation on procedures (5) computer \& projector (6) writing \& speaking (7) authentic printed material

(1) text on four seasons (2) word clustering and formation (3) use (4) topics on four seasons (5) computer and PowerPoint application (6) writing \& speaking (7) authentic printed material

(1) poems (2) rhyme scheme (3) upload (4) posted poem published on blogs or in any form of social media (5) computer and the Internet (6) writing (7) authentic printed material

(1) actor's film biography (2) proper nouns and time expressions (3) share (4) summary of poem biography (5) computer and the Internet (6) writing (7) authentic listening-viewing materials

(1) rhyme schemes (2) words for substitutions (3) edit (4) edited (5) computer and the Internet (6) writing (7) authentic printed material

(1) song lyrics (2) thematic expressions through single nouns (3) structure (4) schema/graphically organized brainstormed words (5) computer \& projector, external disc for download (6) writing \& speaking (7) authentic printed material

(1) pictures of working people (2) present continuous tense (3) integrate (4) captioned photos (5) computer \& projector and Microsoft word application/printer (6) writing \& speaking (7) authentic visual material

(1) recipe (2) action verbs, nouns and sequencing expressions to express process (3) validate (4) categorized words in columns (5) computer \& projector and PowerPoint application (6) listening, viewing, writing \& speaking (7) authentic printed material (1) blog article (2) descriptive words and phrases (3) critique (4) critical analysis (5) computer and downloading tools (6) reading, writing \& speaking (7) authentic printed material

(1) article excerpt (2) declarative (3) post and suggest (4) comments and suggestions (5) computer to access blackboard (6) reading and writing (7) authentic printed material

(1) recorded interview sample (2) noting wh-questions and summarizing responses in groups (3) collaborate (4) notes with wh-questions and summarized responses (5) computer \& projector (6) listening, viewing, writing \& speaking (7) authentic audio-visual material

(1) film clip (2) advice expressions and declaratives in expressing the adverse effects of war (3) review(4) essays (5) computer \& projector (6) listening, viewing, writing \& speaking (7) authentic listening-viewing material 
6. Creating - Constructing a script base from an advertisement viewed in class.

- $\quad$ Sketching and scanning your work to represent the identified theme of an editorial cartoon with a title represented by a conceptualized theme

- $\quad$ Designing a poster to represent your written ideas of a music video and providing a title.

- $\quad$ Producing a narrative out of a short silent film

- Animating an abstract idea through adobe applications based from a given editorial cartoon on war to be entitled using the abstract idea in one single word such as pain, hatred, revenge, compassion and regrets among others.

- $\quad$ Podcasting ideas about a live news as a form of reporting in a condensed form

- $\quad$ Mixing of visuals and sounds to create a moving picture story with subtitles
(1) broadcast/ live advertisement (2) paraphrasing dialogues (3) construct (4) written personal scripts (5) download manager, $\mathrm{CD}$, external disc, computer \& projector (6) listening, viewing, writing \& speaking (7) authentic listening-viewing materials (1) editorial cartoon (2) themes in noun forms (3) sketch and scan (4) scanned sketches entitled by a determined theme (5) download manager, CD, external disc, computer \& projector (6) viewing, writing \& speaking (7) authentic visual material

(1) a music video on family values (2) articles, adjectives and prepositional phrases (3) design and generate (4) posters with title (5) download manager, scanner, computer \& projector (6) listening, viewing, writing \& speaking (7) authentic listening-viewing materials (1) muted silent film (2) simple tenses (3) produce (4) narrative (5) download manager, computer $\&$ projector (6) listening, viewing, writing \& speaking (7) authentic listening-viewing materials

(1) editorial cartoon on war (2) abstract nouns that represent themes (3) animate (4) animation (5) download manager, computer \& projector and adobe applications (6) viewing, writing \& speaking (7) authentic visual material

(1) pictures and sound (2) wh-questions (3) produce (4) power point presentation (5) download manager, scanner, computer \& projector (6) listening, viewing, writing \& speaking (7) authentic visual/authentic listening-viewing materials

(1) pictures/music/script made beforehand (2) sentences according to purpose (3) construct (4) scripts and captioned picture story/PowerPoint (5) moviemaker/computer \& applications (6) listening, viewing, writing \& speaking (7)

authentic visual materials/ authentic listening-viewing materials/ printed material

To explicate, Table 1 indicates how cognitive learning is achieved independently from mixed authentic materials with varied independent tasks to produce different outputs. The first column contains Digital taxonomy of objectives entrenching the order thinking skills' levels: remembering, understanding, applying, analyzing, evaluating, and creating corresponding to the level objectives known as subskills. When teachers employ authentic materials with the facilitation of technological tools, digital and linguistic awareness could be attained as shown in column 2. The role of column 3 is crucial since it constitutes relevant elements in manipulating authentic materials as earlier introduced. It is here that the task elements interact dependently. The authentic material and its type used as an input determine the language targets or focus along with the aid of the specific objectives. The availability of technological tools, such as multimedia that comprises computers and Internet applications in task performance. Moreover, the process stimulates any of the macro skills, such as reading, writing, listening, and speaking as well as the viewing skills. The tasks' outputs are weighed individually according to the order thinking skills and level objectives, where they are classified indicating the extent of cognitive learning.

Table 2. Authentic materials intertwining tasks to produce an over-all independent output

\begin{tabular}{|c|c|c|}
\hline Digital Taxonomy & \multicolumn{2}{|c|}{ Lower Order Thinking Skills Lower Level Objectives } \\
\hline 1. Remembering & $\begin{array}{l}\text { Googling the URL of the Biography Channel to } \\
\text { watch Rock Hudson's biography } \\
\text { Listing down significant events in the life of the } \\
\text { person. List the remarkable achievements the } \\
\text { actor has done }\end{array}$ & $\begin{array}{l}\text { (1) film biography of Rock Hudson (2) verb phrase (3) } \\
\text { Google and list (4) list of achievements (5) computer for } \\
\text { Internet/ projector/downloader/external hard disk/USB stick } \\
\text { (6) listening, viewing and writing (7) listening-viewing } \\
\text { material }\end{array}$ \\
\hline 2. Understanding & $\begin{array}{l}\text { Categorizing or classifying the remarkable } \\
\text { achievement of the actor according to dates or } \\
\text { life's stages }\end{array}$ & $\begin{array}{l}\text { (1) film biography of Rock Hudson (2) dates and other } \\
\text { expressions of time (3) categorize or classify (4) classified } \\
\text { achievement of the actor in terms of dates (5) } \\
\text { computer/computer application/ the projector for further } \\
\text { discussion (6) reading and writing (7) listening-viewing } \\
\text { material }\end{array}$ \\
\hline
\end{tabular}




\begin{tabular}{|c|c|c|}
\hline & \multicolumn{2}{|c|}{ Higher Order Thinking Skills Higher Level Objectives } \\
\hline 3. Applying & $\begin{array}{l}\text { Using proper expressions in statements about the } \\
\text { life of the actor. }\end{array}$ & $\begin{array}{l}\text { (1) film biography of Rock Hudson (2) past simple/time/order } \\
\text { expressions (3) construct (4) series of statements about the } \\
\text { life of the actor with proper time and order expressions (5) } \\
\text { computer application (6) writing, viewing and listening ( } 7 \text { ) } \\
\text { listening-viewing material }\end{array}$ \\
\hline 4. Analyzing & $\begin{array}{l}\text { organizing the achievement and the remarkable } \\
\text { events according to how they occur following the } \\
\text { timeline }\end{array}$ & $\begin{array}{l}\text { (1) film biography of Rock Hudson (2) application of the } \\
\text { three tenses ( } 3 \text { ) organize facts about the actor's life (4) } \\
\text { timeline (5) computer/projector and Microsoft applications } \\
\text { (6) writing (7) listening-viewing material }\end{array}$ \\
\hline 5. Evaluating & $\begin{array}{l}\text { Checking the facts before confirming by using the } \\
\text { timeline }\end{array}$ & $\begin{array}{l}\text { (1) film biography of Rock Hudson (2) agree and disagree } \\
\text { expressions (3) comment/critique (4) summarized timeline } \\
\text { (5) computer/projector and Microsoft applications (6) writing } \\
\text { (7) listening-viewing material }\end{array}$ \\
\hline 6. Creating & $\begin{array}{l}\text { Creating a narrative by putting together the } \\
\text { contents of the timeline and share by blogging }\end{array}$ & $\begin{array}{l}\text { (1) film biography of Rock Hudson (2) past simple and order } \\
\text { expressions (3) create / blog (4) blogged narrative (5) } \\
\text { computer/projector and Microsoft applications (6) writing/ } \\
\text { speaking ( } 7 \text { ) listening-viewing material }\end{array}$ \\
\hline
\end{tabular}

On the other hand, Table 2 explains how cognitive learning is realized out of a single authentic listening-viewing material with interconnecting tasks. In here, the table illustrates how a common authentic material, specifically a film biography, can direct the learners into a hierarchical development of order thinking skills through the performance of activities dependent upon each other in forming an overall output. In Table 2, orders thinking skills and level objectives increase as the activities are performed connectively as cited in Table 1.

Table 3. A single authentic material with varied tasks to produce independent outputs

\begin{tabular}{|c|c|c|}
\hline \multirow{2}{*}{$\begin{array}{l}\text { Digital Taxonomy } \\
\text { 1. Remembering }\end{array}$} & \multicolumn{2}{|c|}{ Lower Order Thinking Skills Lower Level Objectives } \\
\hline & $\begin{array}{l}\text { Searching for the poster and listing functional } \\
\text { and content words from the passage or from } \\
\text { the images found in the posters }\end{array}$ & $\begin{array}{l}\text { (1) film poster (2) content a functional vocabulary (3) } \\
\text { search/list or write (4) listed content words and listed } \\
\text { functional words (5) computer to access the Internet (6) } \\
\text { reading and writing (7) authentic visual material }\end{array}$ \\
\hline 2. Understanding & $\begin{array}{l}\text { Downloading the posters in their computers for } \\
\text { easy access of the images and inferring the } \\
\text { idea of the posters through the images }\end{array}$ & $\begin{array}{l}\text { (1) film poster (2) abstract and concrete nouns through the } \\
\text { symbolic images/concluding expressions (3) downloading } \\
\text { and infer (4) image interpretations/predictions (5) computer } \\
\text { and computer applications with the Internet/projectors (6) } \\
\text { viewing and writing, speaking ( } 7 \text { ) authentic visual material }\end{array}$ \\
\hline & \multicolumn{2}{|c|}{ Higher Order Thinking Skills Higher Level Objectives } \\
\hline 3. Applying & $\begin{array}{l}\text { Presenting a diagram to express ideas/themes } \\
\text { from the poster }\end{array}$ & $\begin{array}{l}\text { (1) film poster (2) usage of declarative statements (3) present } \\
\text { (4) PowerPoint presentation and concept summary (5) } \\
\text { computer/ projector/scanner/download manager, computer } \\
\text { application (6) writing and speaking (7) authentic visual } \\
\text { material }\end{array}$ \\
\hline 4. Analyzing & $\begin{array}{l}\text { Mixing ideas together to comprehend whole } \\
\text { ideas and structuring diagrams to represent } \\
\text { comprehension of the posters' passages }\end{array}$ & $\begin{array}{l}\text { (1) film poster (2) word formation to sentence constructions } \\
\text { (3) mix and structure (4) general concepts of the poster (5) } \\
\text { projector and computer/computer applications (6) writing and } \\
\text { speaking (7) authentic visual material. }\end{array}$ \\
\hline 5. Evaluating & $\begin{array}{l}\text { Reviewing the details of the film as a form of } \\
\text { advertisement. }\end{array}$ & $\begin{array}{l}\text { (1) Film poster (2) WH questions usage (3) check and review } \\
\text { (4) checklist to review the poster's ideas (5) computer and } \\
\text { projector (6) writing and speaking ( } 7 \text { ) authentic visual } \\
\text { material }\end{array}$ \\
\hline 6. Creating & $\begin{array}{l}\text { Designing and composing a poster that restores } \\
\text { similar ideas from the original poster and } \\
\text { composing a brief gist of what the poster wants } \\
\text { to project on audience }\end{array}$ & $\begin{array}{l}\text { (1) Film poster (2) present simple expressions ( } 3 \text { ) design and } \\
\text { compose (4) a poster and its gist (5) projector or monitor, } \\
\text { scanner, computer (6) writing and speaking (7) authentic } \\
\text { visual material }\end{array}$ \\
\hline
\end{tabular}

Lastly, Table 3 explains how cognitive learning is attained from a single authentic visual material to produce independent outputs. In here, the table exemplifies how a common authentic material specifically a film poster can motivate learners through varied designed independent tasks to measure learners' order thinking skills. Similar to Tables 1 and 2, the first column contains the Digital's taxonomy of objectives that embeds the order thinking skills' levels that correspond to the subskills found in the third column. 
To disseminate a clearer understanding of the conceptual relationships of this paper's variables, a paradigm was constructed. Figure 1 attempts to elucidate the relevance of authentic materials as toolkits in language learning. The type of springboard for language instruction dictates the kind of authentic tasks. In the preparation of these tasks, it is suggested that the following elements should be embedded: authentic input, language target(s), specific objectives, expected output, technological aids through multimedia tools, such as computers and Internet applications, macro skills, and the types of authentic material. All these components support each other for the attainment of digital and linguistic skills to demonstrate learners' socio-cognitive ability. The cognitive levels may be performed through collaborative or independent performances. They are measured according to order thinking skills and level objectives. As the order thinking skills ascend from remembering, understanding, applying, analyzing, evaluating to creating; the level objectives increase to indicate the degree of performance as manifested by the rising level objectives. These are achieved through the manipulation of authentic materials fundamentally facilitated by computers and Internet applications employing varied materials patterned from Gebhard's (1996) authentic material classification.

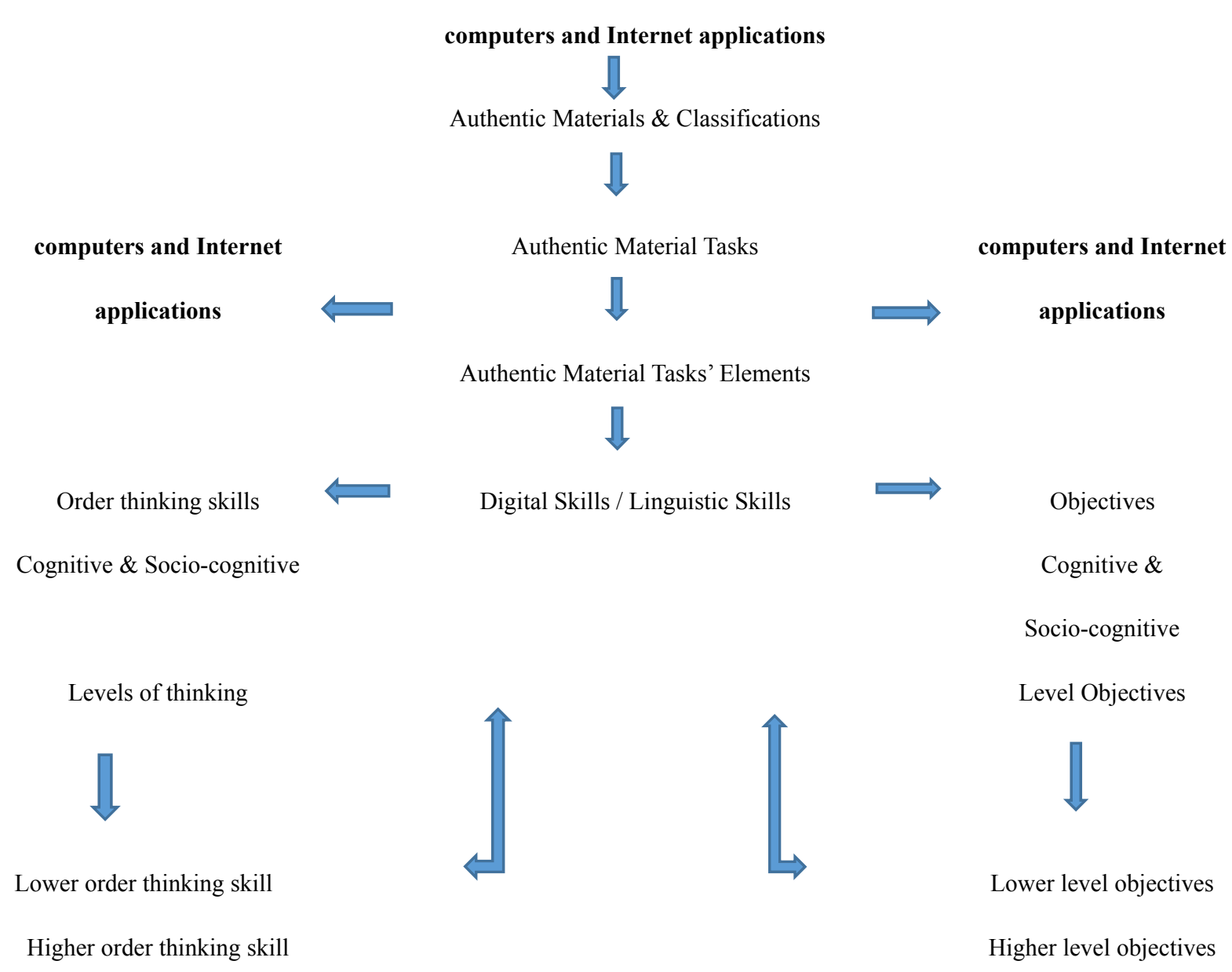

Figure 1. Authentic materials integration to digital taxonomy through integrated CALL

Furthermore, assimilation of order thinking skills under the Digital Taxonomy aided by technological tools and digital tasks to achieve linguistic and digital skills delineates the employment of integrative CALL.

\section{Results}

To summarize the outputs of integrating authentic materials and Digital Taxonomy in language teaching, Table 4 below presents a clearer view by surfacing the elements that define the real concept. 
Table 4. Output table of authentic material approaches

\begin{tabular}{|c|c|c|c|}
\hline \multicolumn{4}{|c|}{ (A) Authentic materials with varied tasks producing varied independent outputs } \\
\hline $\begin{array}{l}\text { Digital Taxonomy } \\
\text { \& Subskills }\end{array}$ & Tools/Materials & Language/skills & outputs \\
\hline $\begin{array}{l}\text { Remembering } \\
\text { Searching, listing, } \\
\text { recognizing, } \\
\text { bookmarking }\end{array}$ & $\begin{array}{l}\text { Website and computers } \\
\text { Essays on world disasters }\end{array}$ & $\begin{array}{l}\text { English alphabets/dates/numbers-reading } \\
\text { and writing }\end{array}$ & $\begin{array}{l}\text { alphabetized list and } \\
\text { sequenced topics based from } \\
\text { dates } \\
\text { (Independent output) }\end{array}$ \\
\hline $\begin{array}{l}\text { Creating } \\
\text { Designing and } \\
\text { generating }\end{array}$ & $\begin{array}{l}\text { music video family values } \\
\text { download manager, scanner, } \\
\text { computer \& projector }\end{array}$ & $\begin{array}{l}\text { articles, adjectives and prepositional } \\
\text { phrases-listening, viewing, writing \& } \\
\text { speaking }\end{array}$ & $\begin{array}{l}\text { posters with title } \\
\text { (Independent output) }\end{array}$ \\
\hline \multicolumn{4}{|c|}{ (B) Authentic material intertwining tasks to produce an over-all independent output } \\
\hline $\begin{array}{l}\text { Remembering } \\
\text { Googling and listing }\end{array}$ & $\begin{array}{l}\text { film biography of Rock Hudson- } \\
\text { computer for } \\
\text { Internet/projector/downloader/ } \\
\text { external hard disk/USB stick }\end{array}$ & verb phrase- listening, viewing and writing & $\begin{array}{l}\text { list of achievements } \\
\text { (dependent output) }\end{array}$ \\
\hline $\begin{array}{l}\text { Understanding } \\
\text { categorize or } \\
\text { classify }\end{array}$ & $\begin{array}{l}\text { film biography of Rock } \\
\text { Hudson-computer/ computer } \\
\text { application/ the projector for } \\
\text { further discussion }\end{array}$ & $\begin{array}{l}\text { dates and other expressions of time } \\
\text {-reading and writing }\end{array}$ & $\begin{array}{l}\text { classified achievement of the } \\
\text { actor in terms of dates } \\
\text { (dependent output) }\end{array}$ \\
\hline $\begin{array}{l}\text { Applying } \\
\text { Using }\end{array}$ & $\begin{array}{l}\text { film biography of Rock } \\
\text { Hudson-computer applications }\end{array}$ & $\begin{array}{l}\text { past simple/order expressions-writing, } \\
\text { viewing and listening }\end{array}$ & $\begin{array}{l}\text { Statements about the life of } \\
\text { the actor in the past with } \\
\text { proper time and order } \\
\text { expressions. } \\
\text { (dependent output) }\end{array}$ \\
\hline $\begin{array}{l}\text { Analyzing } \\
\text { Organizing }\end{array}$ & $\begin{array}{l}\text { film biography of Rock Hudson- } \\
\text { computer/projector and Microsoft } \\
\text { applications }\end{array}$ & past simple/order expressions-writing & $\begin{array}{l}\text { Timeline to organize events } \\
\text { in the actor's life with } \\
\text { labeled expressions } \\
\text { (dependent output) }\end{array}$ \\
\hline $\begin{array}{l}\text { Evaluating } \\
\text { Checking }\end{array}$ & $\begin{array}{l}\text { film biography of Rock } \\
\text { Hudson-computer/projector and } \\
\text { Microsoft applications }\end{array}$ & $\begin{array}{l}\text { agreeing and disagreeing } \\
\text { expressions-speaking and } \\
\text { listening/viewing }\end{array}$ & $\begin{array}{l}\text { Finalized timeline } \\
\text { (dependent output) }\end{array}$ \\
\hline $\begin{array}{l}\text { Creating } \\
\text { Creating and } \\
\text { blogging }\end{array}$ & $\begin{array}{l}\text { film biography of Rock } \\
\text { Hudson-computer/projector and } \\
\text { Microsoft applications }\end{array}$ & past simple/order expressions-writing & $\begin{array}{l}\text { Blogged narrative } \\
\text { (independent output) }\end{array}$ \\
\hline \multicolumn{4}{|c|}{ (C) a single authentic material with varied tasks to produce independent outputs } \\
\hline $\begin{array}{l}\text { Understanding } \\
\text { Inferring / } \\
\text { downloading } \\
\text { Creating } \\
\text { design and compose } \\
\end{array}$ & $\begin{array}{l}\text { film poster/computer and } \\
\text { computer applications with the } \\
\text { Internet/projectors } \\
\text { Film poster projector or monitor, } \\
\text { scanner, computer }\end{array}$ & $\begin{array}{l}\text { Abstract and concrete nouns through the } \\
\text { symbolic interpretations - viewing and } \\
\text { writing, speaking } \\
\text { present simple expressions } \\
\text {-writing and speaking }\end{array}$ & $\begin{array}{l}\text { image interpretations/ } \\
\text { conclusions } \\
\text { Independent output } \\
\text { a poster and its gist } \\
\text { Independent output }\end{array}$ \\
\hline
\end{tabular}

To expound how outputs are generated in language teaching, this table indicates three techniques labeled as: (A) materials with varied tasks in generating varied independent outputs, (B) a material intertwining tasks to construct an over-all independent output and (C) a single material with independent tasks in creating independent outputs. When these three techniques are utilized, they bring the interconnections of digital taxonomy, authentic materials, technological tools and the language and skills to produce outputs. There could be independent outputs and dependent outputs yielded in any of these procedures. As used in this concept, dependent outputs are outputs of tasks that are interconnected with other tasks to produce higher form of outputs. The higher form of outputs created is the independent outputs.

To exemplify, note that this table demonstrates two chosen digital skills in two techniques. In technique A, it uses varied materials Internet (essays and video) both materials have different outputs which are alphabetized lists of essay topics and posters with the title. A lower order thinking skill (remembering) and a higher order thinking skill (creating) were achieved. Secondly, technique B intertwines all the outputs treated as dependent from every task's results from a single springboard to be able to produce the targeted independent output (blogged narratives) from higher order thinking skills. This technique requires the presence of LOTS and HOTS since it intertwines every dependent output from each level to obtain a higher level. Finally, Technique $\mathrm{C}$ uses similar authentic material that enables independent outputs from every task formulated. The kind of outputs to be produced will depend upon the 
type of objectives which teachers want their learners to attain based from order thinking skills in the Digital taxonomy.

\section{Findings}

This paper may not have been quantitatively treated, but its concept offers promising effects to language instructions. First, both writers recognize that integration of authentic materials and digital taxonomy with simple forms of technologies, such as computers and Internet applications tend to be universally useful. Furthermore, both writers perceive that pragmatic innovation in language teaching tend to be an alternative solution to problems on technological tools' scarcity or unavailability for instructions in any educational institution.

Equally important, there could be several approaches to be utilized in the integration of authentic materials, technological tools, and digital taxonomy to carry-out pragmatic integrative CALL. The writers would like to impart the following three techniques used in this study: (1) employing authentic materials with varied tasks producing varied independent outputs, (2) employing a single authentic material with intertwining tasks to produce an over-all independent output, and (3) employing single authentic material with varied tasks to produce independent outputs.

Similarly, it is perceived that applying these inventive strategies may depend on lesson's time frame, students' levels, instructional goals, availability of technological tools, and alignment to duly sanctioned institutional English programs. Moreover, since authentic materials are accessible from flourishing current media-rich environment, they could be designed easily to possibly propel the employment of digital taxonomy for the advancement of critical thinking in language classrooms through teachers as fundamental agents of favorable educational changes.

Finally, they additionally perceive the adaptability of integrative CALL towards learners' performance on real-world tasks designs at any educational institution that advocates this 21 st century practice.

\section{Conclusion}

Majority of authentic materials in the $21^{\text {st }}$ century emanate from wide-ranging forms of media which are products of technological evolution. As technology moves, media experiences changes. From these changes, instructional materials are created from the real-world environment which are persuasively capable of being structured as instruments for language acquisition. Television, film, videos, magazines, newspapers, posters, billboards, computer games, popular music, and all media related Internet and mobile phone contents are prevalent in the lives of students today. It is noteworthy that the foundation years of students should be the crucial stage where media and technology resources are critically and thoroughly accentuated. It is, therefore, suitable to note that today's students live in information and entertainment culture dominated by moving and static images becoming constant evolutionary tools in language education's advancement. From a resourceful teacher's pedagogical point of view, media forms are authentic materials aided by technologies which can facilitate learning. The most practical and innovative way to attain these pedagogical objectives even with the fruition of high technologies is the application of integrative CALL's principles. Through its standards, no learner is left behind. Furthermore, it is not only the language that is honed when we deal with authentic materials propelled by technologies; digital skills powered by the cognitive skills usually enhance language learners' psychomotor skills. This stated idea thoroughly links to the discoveries of Livingstone (2004), who underscored that beside having basic literacy skills, today's generation also needs technology skills.

In conclusion, pragmatic innovation through the role of technological tools and authentic materials to develop critical thinking in language classrooms with careful utilization of digital taxonomy closely relates to integrative CALL. Application of this type of CALL provides the following perceptions in diversified pedagogic viewpoints as summarized:

1) Development of learners' socio-cognitive and cognitive knowledge manifested by language acquisition and digital skills, not to mention the psychomotor and affective development that simultaneously occur and are unconsciously achieved along the process,

2) A way of catering to students' multiple learning styles and interests through constant authentic materials' use facilitated by technological tools specifically computers and Internet applications,

3) Digital taxonomy comprehension alongside order thinking skills and level objectives with the involvement of authentic material components,

4) Achieving some practical concepts on how technologies and authentic materials perform crucial roles in language learning in reciprocating ways, 
5) instigation of innovation among teachers to take part in the contemporary methods of teaching through the empowerment of authentic materials and technological implements in duly recognized pedagogical procedures despite scarcity of educational technologies under any educational institutions,

6) Situating learners in the 21 st century's real-world breakthroughs through authentic springboards and instructional tools that entrench natural interplay of the language,

7) Familiarization of language teachers to relate authentic material instructions to the learning outcomes duly mandated by their educational institutions' English curricula or programs,

8) Explication and indication of major pedagogic significance of all authentic materials regardless of types entrenching characteristics that anchor dominantly with digital acquisition aside from linguistic skills that are attained, and

9) Stressing authentic visual and printed text materials for instructional designs facilitated by technology as to selection, obtaining sources and/or preparation and presentation of tasks to generate linguistic and digital skills.

\section{Recommendations}

An empirical language research alluding to this paper may be favorably conducted quantitatively to find out the correlation or significance of students' critical thinking achievement through the manipulation of digital taxonomy infusing the interplay of modern authentic materials. Additionally, a comparative research to investigate the level of proficiency between language learning outcomes that integrate digital taxonomy to that of results with non-involvement of digital taxonomy in authentic material-designed tasks is highly recommended. Finally, an inquiry that yields the correlation of respondents' learning styles and attitudes to that of digital taxonomy and how integrative CALL plays a significant role to 21 st century learners is likewise suggested.

\section{References}

Abbasian, G., Mahmoudi, H., \& Shahbazi, A. (2016). Improving Intermediate EFL learners' pragmatic competence. Journal of Applied Linguistics and Language Research, 3(5), 264-275.

Abdallah, M., \& Mansour, M., (2015). Virtual task-based situated language-learning with Second life: Developing EFL pragmatic writing and technological self-efficacy. Arab World English Journal, 2, 150 182. https://doi.org/10.2139/ssrn.2843987

Abu-Seileek, A. (2004). Designing a computer assisted language learning program and testing its effectiveness on students 'writing ability in English. PhD Thesis. Amman Arab University for Graduate Studies, Jordan.

Afzal, N., \& Harun, M. (2013). On opinion and persuasive writing: teaching English through editorials. Advances in Language and Literary Studies, 4(2). https://doi.org/10.7575/aiac.alls.v.4n.2p.57

Al-Khayyat, A., (2015). The effect of CALL proposed program on university students' achievement in English. Arab World English Journal (AWEJ), Special Issue(2), 183-194. https://doi.org/10.2139/ssrn.2843988

Alshumaimeri, Y. A., \& Alzyadi, M. A. (2015). Using material authenticity in the Saudi English textbook design: A content analysis from the viewpoint of EFL teachers. Advances in Language and Literary Studies, 6(2), 229-241. https://doi.org/10.7575/aiac.alls.v.6n.2p.229

Amiri, E., Hashemy, S., \& Hayati, D. (2012). A study of the application of digital technologies in teaching and learning English language and literature. International Journal of Scientific \& Technology Research, 1(5), 103-107.

Anderson, L. W., \& Krathwohl, D. R. (2001). A taxonomy for learning, teaching and assessing: A revision of Bloom's taxonomy of educational objectives. New York: Longman.

Banas, J. R., \& York, C. S. (2014). Authentic learning exercises as a means to influence preservice teachers' technology integration self-efficacy and intentions to integrate technology. Australasian Journal of Educational Technology, 30(6), 728-746. https://doi.org/10.14742/ajet.362

Barnes, K., Marateo, R. C., \& Ferris, S. P. (2007). Teaching and learning with the net generation. Innovate, 3(4), 771-772.

Bass, G. M. Jr., \& Perkins, H. W. (1984). Teaching Critical Thinking Skills with CAI. Electronic Learning, 14(2), 32-34.

Baum, R. (1990). Finishing Touches—10 Top Programs. Learning, 18(6), 51-55.

Bayri, G. (2010). The student perception of visual arts in the speaking classroom. International Journal of Arts and Sciences, 3(11), 166-180. Retrieved from 
http://openaccesslibrary.org/images/RLN220_Gaye_Bayri.pdf

Berardo, S. (2006). The Use of authentic materials in the teaching of reading. The Reading Matrix, 6(2), 64-66.

Breen, M. (1985). Authenticity in the language classroom. Applied Linguistics, 6(1), 60-70. https://doi.org/10.1093/applin/6.1.60

Brinton, D. M. (2001). The use of media in language teaching. In C. Murcia (Ed.), Teaching English as a second or foreign language (pp. 459-475). Boston, MA: Heinle and Heinle.

Brosnan, D., Brown, K., \& Hood, S. (1984). Reading in Context. Developing the readingstrategies of adult E.S.L. learners. Adelaide: National Curriculum Resource Center. Australia: NSW AMES.

Canale, M., \& Swain, M. (1980). Theoretical bases of communicative approaches to second language teaching and testing. Applied Linguistics, 1(1), 2-43. https://doi.org/10.1093/applin/1.1.1

Chapelle, C. (1998). Multimedia call: Lessons to be learned from research on instructed SLA. Language Learning and Technology, 2(1), 22-34.

Churches, A. (2008). Bloom's taxonomy. Bloom's digitally. Retrieved January 23, 2017, from https://www.techlearning.com/news/bloom39s-taxonomy-blooms-digitally

Coats, G. (2016). Analyzing song lyrics as an authentic language learning opportunity. Retrieved January 21, 2019, from http://www.csctfl.org/documents/2016Report/1_Coats.pdf

Cotton, K. (1991). Close-Up \#11: Teaching Thinking Skills. Northwest Regional Educational Laboratory's School Improvement Research (p. 5). Retrieved January 25, 2019 from http://www.nwrel.orghttp://educationnorthwest.org/6/cu11.html

Davies, G., \& Steel, D. (1981). First steps in computer-assisted language learning at Ealing College of Higher Education. Paper presented at the CAL 81 Symposium, University of Leeds. Retrieved December 16, 2018, from http://www.ict4lt.org/en/Davis_Steel_1981.doc

Eisenberg, J. (2014). How to teach close reading using a recipe. Retrieved February 22, 2019, from http://blog.leeandlow.com/2014/10/26/how-to-teach-close-reading-using-a-recipe/

Ferlazzo, L. (2012). Using photos with English-language learners. Edutopia. George Lucas Educational Foundation. Retrieved January 22, 2019, from https://www.edutopia.org/blog/ell engagement-using-photos

Firth, J. R. (1957). A synopsis of linguistic theory, 1930-1955. In F. R. Palmer (Ed.), Selected papers of J. R. Firth 1952-1959. London and Harlow: Longman.

Gebhard, J. G. (1996). Teaching English as a foreign language: A teacher self-development and methodology. Ann Arbor: Michigan University Press.

Griffin, L. (2015). Using video in the classroom. Library video company. Retrieved March 18, 2019, from http://www.libraryvideo.com/articles/article13.asp

Hamlaoui, N., \& Benabdallah, N. (2015). Discussion-Based Approach to English Language Teaching and Learning a Digital Dedicated Language Laboratory. Arab World English Journal (AWEJ), Special Issue on CALL(2), 195-206. https://doi.org/10.2139/ssrn.2843990

Hobbs, R. (2011). Digital and Media Literacy: Connecting Culture and Classroom. Thousand Oaks, CA: SAGE Publications.

Hooper, S., \& Rieber, L. P. (1995). Teaching with technology. In A. C. Ornstein (Ed.), Teaching: Theory into practice (pp. 154-170). Needham Heights, MA: Allyn and Bacon.

Jenkins, H. (2009). Confronting the challenges of participatory culture. Cambridge. MA: MIT Press. https://doi.org/10.7551/mitpress/8435.001.0001

Jeong, B. (2007). Learner experiences in web-based language learning. Computer Learning, 20(1), 21-36. https://doi.org/10.1080/09588220601118495

Jones, C., \& Fortescue, S. (1988). Using computers in the language classroom. New York: Longman.

Kao, S. F. (2008). The best time for learning English. Taipei Times. Retrieved March 3, 2019, from http://www.taipeitimes.com/News/editorials/archives/2008/03/25/200340702

Kuang, W. (2000). English teachers' barriers to the use of computer-assisted language learning. The Internet TESL Journal, VI(12). Retrieved December 16, 2018, from http://iteslj.org/ 
Lantolf, J. (2000). Second language learning as a mediated process. Survey Article. Language Teaching, 33, 7996. https://doi.org/10.1017/S0261444800015329

Latif, F. (2012). Application of computer and technology in Iranian Business English courses. Theory and Practice in Language Studies, 2(11), 2284-2290. https://doi.org/10.4304/tpls.2.11.2284-2290

Lave, J., \& Wenger, E. (1991). Situated learning: Legitimate peripheral participation. New York: Cambridge University Press. https://doi.org/10.1017/CBO9780511815355

Lavery, C. (2015). Using cartoons and comic strips. British Council \& BBC. Retrieved December 12, 2018, from https://www.teachingenglish.org.uk/article/using-cartoons

Leech, G. N. (1966). English in Advertising. London: Longman.

Livingstone, S. (2004). Media literacy and the challenge of new information and communication technologies. The Communication Review, 7(1), 4-9. https://doi.org/10.1080/10714420490280152

Lohr. L. (2003). Creating graphics for learning and performance: Lessons visual literacy. Upper Saddle River, N.J. Pearson Education, Inc.

Lombardi, M. (2007). Authentic learning for the 21st century: An overview. Retrieved March 1, 2019, from https://library.educause.edu/resources/2007/1/authentic-learning-for-the-21stcentury-an-overview

Losada, C., Insuasty, E., \& Osorio, M. (2016). The impact of authentic materials and tasks on students' communicative competence at a Colombian Language School. Teachers' Professional Development, 19(1), 89. https://doi.org/10.15446/profile.v19n1.56763

Lovell, J. (1987). Potential applications are wide-ranging. Ed300848 1988-00-00 using film, video and TV in the classroom. Mentioned by ERIC Development Team. ERIC Digest, 11. Retrieved March 5, 2019, from http://files.eric.ed.gov/fulltext/ED300848.pdf

Mackenzie, W. (2012). Intelligence Quest. Project-based learning and multiple intelligences international society for technology in education. USA: ISTE.

Mahib urRahman, M., \& Alhaisoni, E. (2013). Teaching English in Saudi Arabia: Prospects and challenges. Academic Research International, 4(1), 112-118.

McEnery, T., Barker, A., \& Wilson, A. (1995). A Statistical Analysis of Corpus Based Computer versus Traditional Human Teaching Methods of Part of Speech Analysis. Computer Journal Assisted Language Learning, 8(2), 259-274. https://doi.org/10.1080/0958822940080208

McGrath, I. (2002). Materials Evaluation and design for language teaching. Edinburgh: Edinburgh University Press.

McKenzie, P. (2012). Painting a picture of the teaching workforce. Research Developments, 27(2), 1-5.

McLoughlin, C., \& Lee, M. J. W. (2007). Social software and participatory learning: Pedagogical choices with technology affordances in the web 2.0 era. Paper presented at the ICT: Providing choices for learners and learning. Proceedings ascilite Singapore. Retrieved February 9, 2019, from http://dlcubc.ca/dlc2wp/educ500/files/2011/07/mcloughlin.pdf

Melvin, B. S., \& Stout, D. S. (1987). Motivating language learners through authentic materials. In W. Rivers (Ed.), Interactive Language Teaching. New York: Cambridge University Press.

Miller, R. (2011). Deconstructing film posters. Retrieved January 22, 2019, from http://film.edusites.co.uk/article/deconstructing-film-posters/

Motteram, G. (2013). The Benefits of new technology in language learning. Retrieved April 23, 2019, from http://www.britishcouncil.org/voices-magazine/the-benefits-newtechnologylanguage-learning

Nunan, D. (1999). Second Language Teaching and Learning. Boston: Heinle and Heinle Publishers.

Nuttal, C. (1996). Teaching reading skills in a foreign language (New Edition). Oxford: Heinemann.

Pogrow, S. A. (1988). Evaluation of the Chapter 1 higher order thinking skills project. Report prepared for the Program Effectiveness Panel of the National Diffusion Network. Tucson: University of Arizona, College of Education.

Prensky, M. (2001). Digital Game-Based Learning (1st ed.). New York: McGraw Hill Press. https://doi.org/10.1145/950566.950596

Reisland, E. (2009). New horizons for learning. Visual literacy and the classroom. Retrieved March 21, 2019, 
from http://www.newhorizons.org/strategies/literacy/reisland.htm

Richard, J. C. (2001). Curriculum development in language teaching. Cambridge: Cambridge University Press. https://doi.org/10.1017/CBO9780511667220

Riding, R. J., \& Powell, S. D. (1987). The Effect on Reasoning, Reading and Number Performance of Computer-presented Critical Thinking Activities in Five-year-old Children. Educational Psychology, 7(1), 55-65. https://doi.org/10.1080/0144341870070107

Rogers, C. V., \& Medley, F. W. J. (1988). Language with a purpose: Using authentic materials in the foreign language classroom. Foreign Language Annals, 21, 467-478. https://doi.org/10.1111/j.1944-9720.1988.tb01098.x

Salomon, G. (1997). Novel constructivist learning environments and novel technologies: Some issues to be concerned with. Presented at EARLI, Athens, and August 1997. Retrieved December 14, 2018, from http://cybercon98.Harvard.edu/wcm/sal_article.html

Sweeting. A. (2009). Language through Film. Sydney Phoenix Education Pty. Limited.

Thomas, M., Hayo, R., \& Warschauer, M. (2013). Contemporary computer-assisted language learning. Newgen Imaging Systems Pvt Ltd, Chennal, India. Great Britain.

Thorne, S., \& Payne, J. (2005). Evolutionary trajectories, Internet-mediated expression, and language education. CALICO Journal, 22(3), 371-397. https://doi.org/10.1558/cj.v22i3.371-397

Tomalin, B., \& Stempeski, S. (1988). Cultural Awareness. Oxford: Oxford University Press.

Tuzi, F., Mori, K., \& Young, A. (2008). Using TV commercials in ESL/EFL classes. The Internet TESL Journal, $14,5-11$.

Vestergaard, T., \& Schroder, K. (1985). The language of advertising. Oxford: B. Blackwell.

Warschauer, M. (1996). Computer Assisted Language Learning: An Introduction. In Fotos S. (Ed.), Multimedia language teaching (pp. 3-20). Tokyo: Logos International.

Warschauer, M., \& Healey, D. (1998). Computers and language learning: an overview. Language Teaching Forum, 31, 57-71. https://doi.org/10.1017/S0261444800012970

Williams III, S. E. (1999). Teaching Academic Skills through the Exploration of Music. Retrieved April 12, 2019, from http://www.yale.edu/ynhti/curriculum/units/1995/2/95.02.11.x.html

Wood, D. J. (1995). Good video movies for teaching English as a foreign or second language. Bulletin of the International Cultural Research Institute of Chikushi Jogakuen College, 6, 105-125.

Zane Education. (2015). The benefits of using educational video in the classroom. Retrieved March 23, 2019, from http://www.zaneeducation.com/educational-video/education-andvideo.php

Zhang, H. (2012). The application of English movies in higher vocational English teaching. Sino-US English Teaching, 9(3), 1010-1014.

Zhu, Z. (2003). Teachers' professional development in technology-pedagogy integration: experiences and suggestions. $\quad$ Retrieved May 11, 2019, from http://www.unescobkk.org/education/ict/ictin-education-projects/trainingofteachers/training-of-teachers-and -facilitators/experts meeting-june-2003/papers/china/

Zong, G. (2008). Developing preservice teachers' global understanding through computer mediated communication technology. Teaching and Teacher Education, 25(5), 617-625. https://doi.org/10.1016/j.tate.2008.09.016

Zucker, A., Staut, C., \& Tinker, R. (2015). Teaching graph literacy across the curriculum. https://doi.org/10.2505/4/ss15_038_06_19

\section{Copyrights}

Copyright for this article is retained by the author, with first publication rights granted to the journal.

This is an open-access article distributed under the terms and conditions of the Creative Commons Attribution license (http://creativecommons.org/licenses/by/4.0/). 